UDK 517.5

\author{
A. M. Pasko* \\ * Oles Honchar Dnipro National University, \\ Dnipro 49050.E-mail:pasko08@meta.ua
}

\title{
The homology groups of the space $\Omega_{n}(m)$
}

\begin{abstract}
У статті введено простір $\Omega_{n}(m)$, як певне узагальнення просторів узагальнених досконалих сплайнів $\Omega_{n}$. Сплайни простору $\Omega_{n}(m)$, на відміну від сплайнів простору $\Omega_{n}$, набувають значень не \pm 1 , а значень серед множини $G_{m}$, яка складається $3 \mathrm{~m}$ рівновіддалених вузлів одиничного кола комплексної площини. Як і для простору $\Omega_{n}$, топологія простору $\Omega_{n}(m)$ наслідувана з $L_{1}$. При $m=2$ простір $\Omega_{n}(2)$ збігається з простором $\Omega_{n}$. Систематичне дослідження гомотопічних інваріантів простору $\Omega_{n}$ було започатковане B.I. Рубаном, який побудував клітинну структуру цього простору, і з її допомогою 1985 року знайшов групи $n$-вимірних гомологій простору $\Omega_{n}$, а 1999 року повністю розв'язав задачу відшукання груп його когомологій. В подальшому гомотопічні інваріанти простору $\Omega_{n}$ вивчалися В.А. Кощеевим, який встановив однозв'язність $\Omega_{n}$, та А.M. Паськом, який знайшов гомотопічні групи цих просторів у вимірностях від 2 до $n$. Задля вивчення гомотопічних інваріантів простору $\Omega_{n}(m)$ введено клітинну структуру цього простору, яка узагальнює побудовану B.I. Рубаном клітинну структуру простору $\Omega_{n}$. Кожна клітина простору $\Omega_{n}(m)$ має вигляд $c^{q}\left(l_{0}, l_{1}, \ldots, l_{q}\right)$, де $q, q \leq n$, є кількість вузлів сплайнів, з яких складається клітина, а $l_{0}, l_{1}, \ldots, l_{q}$ є номери значень множини $G_{m}$, яких набувають сплайни на відповідних інтервалах, для кожної клітини побудовано характеристичне відображення. Таким чином, $\Omega_{n}(m)$ перетворено на $n$-вимірний клітинний простір. Побудована клітинна структура простору $\Omega_{n}(m)$ дозволяє легко обчислити кількість клітин у кожній вимірності. Ейлерова характеристика будьякого скінченновимірного клітинного простору виражається через кількості клітин у кожній вимірності, що дозволило обчислити ейлерову характеристику просторів $\Omega_{n}(m)$, потрібну для обчислення його гомологічних груп. 3 допомогою введеної клітинної структури простору $\Omega_{n}(m)$ також з'ясовано вигляд межового оператора на групах ланцюгів цього простору. Для обчислення гомологічних груп клітинного простору $\Omega_{n}(m)$ введено оператор $D: C_{q}\left(\Omega_{n}(m)\right) \rightarrow C_{q+1}\left(\Omega_{n+1}(m)\right)$, що діє з групи $q$ вимірних ланцюгів простору $\Omega_{n}(m)$ у групу $q+1$-вимірних ланцюгів простору $\Omega_{n+1}(m)$. Зазначимо, що простір $\Omega_{n}(m)$ завжди є підмножиною простору $\Omega_{n+1}(m)$, що дозволяє розглянути оператор вкладення $i: \Omega_{n}(m) \rightarrow \Omega_{n+1}(m)$, який породжує гомоморфізм $\bar{i}: C_{q}\left(\Omega_{n}(m)\right) \rightarrow C_{q}\left(\Omega_{n+1}(m)\right)$ відповідних груп клітинних ланцюгів. Побудований вище оператор $D$ разом із формулою для обчислення межового оператора дозволяє довести що у всіх вимірностях $q \geq 1$ оператор $\bar{i}$ ланцюгово гомотопний тривіальному, а отже ним породжений оператор $i_{*}$ тривіальний. Тривіальність цього оператора, разом із технікою точної гомологічної послідовності пари дозволяє встановити тривіальність груп гомологій простору $\Omega_{n}(m)$ у вимірностях від 1 до $n-1$. Оскільки простір однозв'язний, то його 0-вимірна група гомологій ізоморфна адитивній групі цілих чисел. Отже, нами знайдено всі гомологічні групи просторів $\Omega_{n}(m)$ у вимірностях від 0 до $n-1$. Підрахунок ейлерової характеристики дозволяє знайти $n$-вимірні групи гомологій.
\end{abstract}


Key words: узагальнені досконалі сплайни, клітинний простір, групи гомологій

The spaces $\Omega_{n}(m)$ that generalize the spaces $\Omega_{n}$ are introduced. In order to investigate the homotopy invariants of the space $\Omega_{n}(m)$ the $\mathbf{C W}$-structure of the space is $\Omega_{n}(m)$ is build. Using exact homology sequence the homology groups of the space $\Omega_{n}(m)$ are calculated.

Key words: generalized perfect spline, $C W$-complex, homology groups

MSC2010: Pri 41A10, SEC 41A44, 46E20

Let $\omega(t), t \geq 0$, be the non-negative, continuous increasing function, $\omega(0)=0$. Consider integer $q \geq 0$, integer $m \geq 2$ and the system of the knots

$$
0=\eta_{0}<\eta_{1}<\ldots<\eta_{q}<\eta_{q+1}=1 .
$$

Let $F(\eta, s, t)$ be the function ( $\omega$-spline)

$$
F(\eta, s, t)=s_{k} \cdot \min \left\{\omega\left(t-\eta_{k-1}\right), \omega\left(\eta_{k}-t\right)\right\}, \quad \text { for } \quad t \in\left[\eta_{k-1}, \eta_{k}\right],
$$

with

$$
s_{k} \in G_{m}=\left\{e^{i \frac{2 \pi l}{m}}: l=0,1, \ldots, m-1\right\} .
$$

Denote by $\Omega_{n}(m), n \geq 2$, the subspace of the space $L_{1}[0,1]$ that consists of the splines (1) for $q \leq n$. The space $\Omega_{n}(2)$ coincides with the space $\Omega_{n}$ that has been studied in [1], [2], [4], [5]. V.I. Ruban [4], [5] has built CW structure on $\Omega_{n}$ and calculated the cohomologies of the space $\Omega_{n}$

$$
H^{k}\left(\Omega_{n}\right)= \begin{cases}\mathbb{Z}, & k=0, \\ \mathbb{Z}^{\frac{2^{n+2}+(-1)^{n+1}}{3}}, & k=n, \\ 0, & k \neq 0, n .\end{cases}
$$

V.A.Koshcheev [1] has proved that the spaces $\Omega_{n}$ are simply connected. A.M. Pasko [2] has established that the homotopy groups

$$
\pi_{k}\left(\Omega_{n}\right)= \begin{cases}0, & 2 \leq k \leq n-1, \\ \mathbb{Z}^{\frac{2^{n+2}+(-1)^{n+1}}{3}}, & k=n .\end{cases}
$$

The space $\Omega_{n}(m)$ is the generalization of the space $\Omega_{n}$. Thus the problem of finding of their homotopy invariants is of interest. In order to investigate the homotopy invariants of the space $\Omega_{n}(m)$ we will construct the structure of CW-complex on $\Omega_{n}(m)$ which is analogue of the CW-structure $\Omega_{n}$ build in [4], [5].

CW-complex is a Hausdorff space $E$ written as a union

$$
E=\bigcup_{q=0}^{\infty} \bigcup_{k \in I_{q}} e_{k}^{q}
$$

of the non-overlapping sets $e_{k}^{q}$ (q-cells) in such a way that any q-cell $e_{k}^{q}$ has a continuous characteristic map $f_{k}^{q}: D^{q} \rightarrow E$ of closed q-dimensional ball $D^{q}$ to E such that the 
restriction of $f_{k}^{q}$ to $\operatorname{Int} D^{q}$ is a homeomorphism between $\operatorname{Int} D^{q}$ and $e_{k}^{q}$. Herewith $\mathrm{E}$ satisfies the conditions:

(C) the boundary $\dot{e}_{k}^{q}=\bar{e}_{k}^{q} \backslash e_{k}^{q}$ of any q-cell lies in the union of a finite number of j-cells for $j<q$;

(W) subset $F \subset E$ is closed if and only if all the intersections $F \cap \bar{e}_{k}^{q}$ are closed.

The q-skeleton of the CW-complex $E$ is the union $\operatorname{ske}_{q}(E)=\bigcup_{j \leq q} e_{k}^{j}$. The CWcomplex $E$ is said to be finite if it consists of finite amount of cells.

Let $q$ be the nonnegative integer. Consider the collection of integers

$$
l_{0}, l_{1}, \ldots, l_{q} \in\{0,1, \ldots, m-1\} .
$$

Let the q-cell $c^{q}\left(l_{0}, l_{1}, \ldots, l_{q}\right)$ be the set of the $\omega$-splines (1) for

$$
s_{k}=e^{i \frac{2 \pi l_{k-1}}{m}}, k=1,2, \ldots, q+1 .
$$

Thus

$$
\Omega_{n}(m)=\bigcup_{q=0}^{n} \bigcup_{l_{0}, l_{1}, \ldots, l_{q}} c^{q}\left(l_{0}, l_{1}, \ldots, l_{q}\right)
$$

In order to build characteristic map of q-cell $c^{q}\left(l_{0}, l_{1}, \ldots, l_{q}\right)$ write the closed ball $D^{q}$ as the simplex

$$
B^{q}=\left\{x=\left(x_{0}, x_{1}, \ldots, x_{q}\right) \in \mathbb{R}^{q}: x_{k} \geq 0, \sum_{k=0}^{q} x_{k}=1\right\} .
$$

For any $x=\left(x_{0}, x_{1}, \ldots, x_{q}\right) \in B^{q}$ consider the system of knots

$$
\eta_{k}(x)=\sum_{j=0}^{k-1} x_{j}, k=1, \ldots, q+1, \eta_{0}(x)=0, \quad \eta(x)=\left(\eta_{0}(x), \eta_{1}(x), \ldots, \eta_{q+1}(x)\right),
$$

Then define the characteristic map $\pi_{l_{0}, l_{1}, \ldots, l_{q}}^{q}: B^{q} \longrightarrow \Omega_{n}(m)$ of the cell $c^{q}\left(l_{0}, l_{1}, \ldots, l_{q}\right)$ by the equality

$$
\pi_{l_{0}, l_{1}, \ldots, l_{q}}^{q}(x)=F(\eta(x), s, *),
$$

where the system of knots $\eta(x)$ is defined by (3) and the system of coefficients $s=\left\{s_{k}\right\}$ is defined by (2).

Consider CW-complex E. The set of the q-cells of $\mathrm{E}$ may be used as the basis of a free abelian group $C_{q}(E)$. Elements of $C_{q}(E)$ are called q-chains. There are the homomorphisms of groups $\partial=\partial_{q}: C_{q}(E) \rightarrow C_{q-1}(E)$. This homomorphisms are called boundary operators. Consider the groups $Z_{q}(E)=\operatorname{Ker} \partial_{q}$ (the groups of $q$-cycles) and $B_{q}(E)=\operatorname{Im} \partial_{q+1}$ (the groups of $q$-boundaries). The identity $\partial_{q} \partial_{q+1}=0$ implies $B_{q}(E) \subset Z_{q}(E)$ that allows to define the homology groups $H_{q}(E)=Z_{q}(E) / B_{q}(E)$. 
It is obvious that the boundary of the q-cell $c^{q}\left(l_{0}, l_{1}, \ldots, l_{q}\right)$ of the space $\Omega_{n}(m)$ is given by

$$
\partial c^{q}\left(l_{0}, l_{1}, \ldots, l_{q}\right)=\sum_{k=0}^{q}(-1)^{k} c^{q-1}\left(l_{0}, \ldots \hat{l}_{k} \ldots l_{q}\right)
$$

where the sequence $\left(l_{0}, \ldots \hat{l}_{k} \ldots l_{q}\right)$ is $\left(l_{0}, \ldots, l_{k-1}, l_{k+1} \ldots l_{q}\right)$.

The sum

$$
\chi(E)=\sum_{k}(-1)^{k} \operatorname{rank} H_{k}(E)
$$

is called the Euler characteristic of a space E. A.M. Pasko and Y.O. Orekhova [3] proved the following lemma.

Lemma 1. The Euler characteristic of the space $\Omega_{n}(m)$ equals

$$
\chi\left(\Omega_{n}(m)\right)=\frac{m}{m+1}\left(1+(-1)^{n} m^{n+1}\right) .
$$

Proof. For the sake of completeness let us prove the lemma. It is known that the Euler characteristic of the finite $\mathrm{CW}$-complex $E$ equals

$$
\chi(E)=\sum_{k}(-1)^{k} v_{k}
$$

where $v_{k}$ is the amount of the $k$-cells of $E$. The amount of the $q$-cells $c^{q}\left(l_{0}, l_{1}, \ldots, l_{q}\right)$ is equal $m^{q+1}$, so

$$
\chi\left(\Omega_{n}(m)\right)=\sum_{q=0}^{n}(-1)^{q} m^{q+1}=\frac{m+(-1)^{n} m^{n+2}}{m+1}=\frac{m}{m+1}\left(1+(-1)^{n} m^{n+1}\right) .
$$

The proof is completed.

The main result of our paper is the following theorem.

Theorem 1. The homology groups of the space $\Omega_{n}(m), m \geq 2, n \geq 2$, are equal

$$
H_{k}\left(\Omega_{n}(m)\right)= \begin{cases}\mathbb{Z}, & k=0, \\ 0, & k \neq 0, n, \\ \mathbb{Z}^{\frac{m^{n+2}+(-1)^{n+1}}{m+1}}, & k=n .\end{cases}
$$

Proof of theorem. Consider the homomorphism $D: C_{q}\left(\Omega_{n}(m)\right) \rightarrow C_{q+1}\left(\Omega_{n+1}(m)\right)$ defined on the generators by the equality

$$
D c^{q}\left(l_{0}, l_{1}, \ldots, l_{q}\right)=c^{q+1}\left(0, l_{0}, l_{1}, \ldots, l_{q}\right) .
$$

By virtue of (4)

$$
\partial D c^{q}=c^{q}-D \partial c^{q}
$$


for any q-cell $c^{q} \in C_{q}\left(\Omega_{n}(m)\right), q \geq 1$. The inclusion $i: \Omega_{n}(m) \rightarrow \Omega_{n+1}(m)$ induces the homomorphism $\bar{i}: C_{q}\left(\Omega_{n}(m)\right) \rightarrow C_{q}\left(\Omega_{n+1}(m)\right)$ of the groups of q-chains and the homomorphism $i_{*}: H_{q}\left(\Omega_{n}(m)\right) \rightarrow H_{q}\left(\Omega_{n+1}(m)\right)$ of the homology groups. It follows from (7) that

$$
\bar{i} c^{q}=\partial D c^{q}+D \partial c^{q}, \quad q \geq 1 .
$$

Therefore for any $q \geq 1$ the homomorphism $i_{*}: H_{q}\left(\Omega_{n}(m)\right) \rightarrow H_{q}\left(\Omega_{n+1}(m)\right)$ is trivial: $i_{*}=0$.

It is obvious that for $q \leq n$ the q-skeleton $\operatorname{ske}_{q}\left(\Omega_{n}(m)\right)=\Omega_{q}(m)$, so the relative homology groups

$$
H_{k}\left(\Omega_{n}(m), \Omega_{n-1}(m)\right)=0, \quad k<n .
$$

Consider the exact homology sequence of the pair $\left(\left(\Omega_{n+1}(m), \Omega_{n}(m)\right),(k>0)\right.$

$$
\begin{gathered}
\ldots \rightarrow H_{k+1}\left(\Omega_{n+1}(m), \Omega_{n}(m)\right) \stackrel{\partial}{\rightarrow} H_{k}\left(\Omega_{n}(m)\right) \stackrel{i_{*}=0}{\rightarrow} H_{k}\left(\Omega_{n+1}(m)\right) \stackrel{j_{*}}{\rightarrow} \\
\stackrel{j_{*}}{\rightarrow} H_{k}\left(\Omega_{n+1}(m), \Omega_{n}(m)\right) \rightarrow \ldots
\end{gathered}
$$

By virtue of (8) for $1 \leq k<n$ it turns into

$$
0 \rightarrow H_{k}\left(\Omega_{n}(m)\right) \stackrel{i_{*}=0}{\longrightarrow} H_{k}\left(\Omega_{n+1}(m)\right) \rightarrow 0 .
$$

This implies that

$$
H_{k}\left(\Omega_{n}(m)\right)=0, \quad 1 \leq k<n .
$$

The space $\Omega_{n}(m)$ is path-connected, so

$$
H_{0}\left(\Omega_{n}(m)\right)=\mathbb{Z}
$$

It follows from (5), (9), (10) that the Euler characteristic of the space $\Omega_{n}(m)$

$$
\begin{gathered}
\chi\left(\Omega_{n}(m)\right)=\sum_{k=0}^{n}(-1)^{k} \operatorname{rank} H_{k}\left(\Omega_{n}(m)\right)=1+(-1)^{n} \operatorname{rank} H_{n}\left(\Omega_{n}(m)\right)= \\
=\frac{m}{m+1}\left(1+(-1)^{n} m^{n+1}\right) .
\end{gathered}
$$

Therefore

$$
\operatorname{rank} H_{n}\left(\Omega_{n}(m)\right)=\frac{m^{n+2}+(-1)^{n+1}}{m+1} .
$$

The CW-complex $\Omega_{n}(m)$ has not the cells in the dimensions greater than $n$, so $H_{n}\left(\Omega_{n}(m)\right)$ is a free abelian group and

$$
H_{n}\left(\Omega_{n}(m)\right)=\mathbb{Z}^{\frac{m^{n+2}+(-1)^{n+1}}{m+1}} .
$$

The proof is completed. 


\section{A. M. PASKO}

\section{References}

1. Koshcheev $V$. A. The fundamental groups of the spaces of generalized perfect splines. Trudy Instituta Matematiki i Mekhaniki UrO RAN V. 15, №1. (2009), 159-165.

2. Pasko A. M. On the homotopy of the spaces of generalized perfect splines. Visn. Dnipro univ., Ser. Mat. 17 (2012), 138-140.

3. Pasko A. M., Orekhova Y. O. The Euler characteristic of the space $\Omega_{n}(m)$. Zbirnik centru naukovikh publikaciy "Veles"za materialami IV mizhnar. nauk.-prakt. konf. «Innovaciyni pidkhodi i suchasna nauka». March, p. 2. Kiyiv. (2018), 65-66

4. Ruban V. I. The CW-structure of the spaces of $\Omega$-splines. Issledovania po sovr. problemam summirovania i priblizhenia funkciy i ikh prilozheniam. Dnipropetrovsk. (1985), 39-40.

5. Ruban V. I. The CW-structure and the cohomology of the spaces of generalized perfect splines. Visn. Dnipro univ., Ser. Mat. 4 (1999), 85-90.

Received: 02.04.2019. Accepted: 10.06.2019 